\title{
Spirituality and Severity of Menopausal Symptoms in a Sample of Religious Women
}

\author{
Patrick R. Steffen · Marilyn Soto
}

Published online: 28 August 2009

(C) Springer Science+Business Media, LLC 2009

\section{Erratum to: J Relig Health \\ DOI 10.1007/s10943-009-9271-9}

The second author is missing from the author list. It should read as follows:

Marilyn Soto

Psychology

Brigham Young University

284 TLRB

Provo, UT 84602

The online version of the original article can be found under doi:10.1007/s10943-009-9271-9.

\section{P. R. Steffen ( $\square)$}

Clinical Psychology, Brigham Young University, 284 TLRB, Provo, UT 84602, USA

e-mail: steffen@byu.edu

M. Soto

Psychology, Brigham Young University, 284 TLRB, Provo, UT 84602, USA

글 Springer 